\title{
Relationship between Foreign Exchange Rate and Stock Price of Commercial Joint Stock Banks: Evidence from Vietnam
}

\author{
Tran Mong Uyen Ngan ${ }^{1}$ \\ ${ }^{1}$ School of Economics, Huazhong University of Science and Techonology, Wuhan, P. R. China \\ Correspondence: Tran Mong Uyen Ngan, School of Economics, Huazhong University of Science and \\ Techonology, Wuhan, P. R. China. E-mail: tranmonguyenngan@yahoo.com
}

Received: April 15, 2016

Accepted: May 3, 2016

Online Published: June 25, 2016

doi:10.5539/ijef.v8n7p193

URL: http://dx.doi.org/10.5539/ijef.v8n7p193

\begin{abstract}
The relationship between foreign exchange rate and stock price is one popular topic that is interested by not only board managers of banks but also stock investors. By using data about foreign exchange rate between Vietnam Dong (VND) and United State Dollar (USD), stock prices data of nine commercial joint stock banks in Vietnam from the first day of 2013 to the last day of 2015, this paper try to answer the question "Does foreign exchange rate impact on stock price and vice verse?". Applying Dickey Fuller test and Var Granger Causality test for the time series data, the results show that there is an impact of foreign exchange rate on stock price. Although the fluctuation in foreign exchange rate VND/USD causes the change in stock prices of commercial joint stock banks in Vietnam, however, the vector of this impact is not clearly. On the opposite way, the change in stock price does not cause the change in foreign exchange rate, this relation is one-way relation.
\end{abstract}

Keywords: causality, foreign exchange market, stock market, VAR granger causality model, volatility spillover

\section{Introduction}

Commercial joint stock banks have important role in credit market, beside doing business on credit market, some commercial joint stock banks also do business on stock market. Stock price of commercial banks in Vietnam in time period of 2006-2007 was named as the "King stock" by investors. However, after the financial crisis of 2007-08, not only stock markets on the world but also stock market in Vietnam face many risks. Although the business of these commercial joint stock banks still bring good results, their stock prices do not keep credit status like in the past. In order to control stock market in Vietnam, there are many research to find factors that impact stock market, however, almost authors focus on factor consumer price index and factor stock price of the world. For this research, we examine factor foreign exchange rate as one factor that impacts on stock prices of commercial joint stock banks in Vietnam, we also examine the impact of stock prices on foreign exchange rate.

\section{Literature Review}

According to the theoretical link between foreign exchange rate and stock price, foreign exchange rate has an indirect impact on stock price through an impact on investors.

\section{Foreign exchange rate fluctuation}

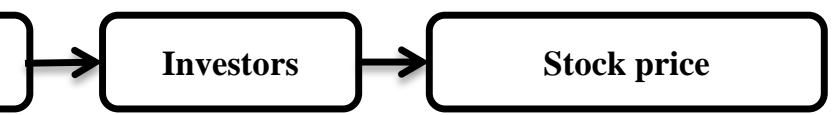

Investors on stock market in general and investor who invest on stock fund or foreign stock in special, always consider about two problems: Stocks that they own and the price of currency that they use to buy this stock. In case of foreign exchange rate VND/USD, examining investors who own stocks in USD, if the price of USD increases, means foreign exchange rate VND/USD decreases, investors who own stocks in USD will get more benefits, vice verse. Because the returns become larger, these investors will consider about stronger investment on this foreign stock, and the final result of these actions is an appreciation of this foreign stock. By this way, the fluctuation in foreign exchange rate lead to a fluctuation in stock price. (Mougoue, 1996) analyzed this relationship in short-run and long-run, examined in United State and in United Kingdom and the results showed that there are covariance relationship between foreign exchange rate and stock price, means depreciation in currency leads to a decline in stock prices. The research of (Yang, 2000), for some of the Asian countries has the same result. To answer the question: "Stock and Currencies: Are they Related?", the research of (Izan, 1999) 
found that there is no relationship between foreign exchange rate and stock price in long-run. Inheritting finding from the research of Ong and Izan, examining the relationship between foreign exchange rate and stock price in G-7 countries, (Lee, 2001) found the same result. Analyzing for China, (Zhao, 2010) found bi-directional volatility spillover effects between the Reminbi (RMB) and stock index of Shanghai market, indicating that past conditional variances in stock market have impact on future volatility in foreign exchange rate market, and vice verse.

The relationship between stock price and foreign exchange rate is also stated in many research of (Desislava, 2005), (Tabak, 2006), (Kutty, 2010), (Kurihara, 2006) and (Sekmen, 2011). In Vietnam, there are some studies about this subject such as the research of (Nga, 2013), (Minh, 2015) and (Long, 2010). The subjects of these researches are import- export enterprises. Inheriting results from the research on the world and the research in Vietnam above, we analyze impact of foreign exchange rate fluctuation on stock price in long-run for commercial joint stock banks in Vietnam.

\section{Model Specification}

We use VAR Granger Causality test to find relationship between foreign exchange rate and stock prices of commercial joint stock banks in Vietnam. This is the main method of this research, and it is applied for analyzing stocks of nine commercial joint stock banks in Vietnam. Beside VAR Granger Causality test, we also use ADF test to be sure that time series data that we use is stationary because stationary is seen as the first requirement of VAR Granger Causality test.

ADF test is fully called "Augmented Dickey-Fuller" test. This test is proposed in the research of two authors named David Dickey and Wayne Fuller (Dickey, 1979) and it is developed by the same authors in 1981 (Dickey, 1981). Later, this test is guided and used popularly in many research when authors want to run regression models as well as Arima or Var models in science research. Some research that used ADF test can be listed as: the research of (Cheung, 1995) and (Xiao, 1998). Specially, ADF is stated in banking with its using in the rearch of Lavan Mahadeva and Paul Robinson (Mahadeva, 2004), the research of (Wickremasinghe, 2004) about foreign exchange markets also used ADF test in the first step for testing stationary for foreign exchange rate variable. Basically, ADF test is easily understood as follow:

Suppose that regression model we build is defined as follow:

$$
\text { FOREX } X_{t}=\alpha+\beta F O R E X_{t-1}+\varepsilon_{t}
$$

Where FOREX $X_{t}$ is variable foreign exchange rate, $t$ is time index, $\alpha$ is coefficient, $\varepsilon_{t}$ is error

In this test we do not care about $\alpha$, that means $\alpha$ is not specified whether equal 0 or unequal 0 .

We also have $\triangle F O R E X_{t}=F O R E X_{t}-F O R E X_{t-1}$

(1) Can be written as follow:

$$
\begin{gathered}
\text { FOREX }_{t}-\text { FOREX }_{t-1}=\alpha+(\beta-1) \text { FOREX }_{t-1}+\varepsilon_{t} \\
\text { AFOREX } \\
t=\alpha+(\beta-1) \text { FOREX }_{t-1}+\varepsilon_{t}
\end{gathered}
$$

Let 's denote $\delta=\beta-1$, then we have

$$
\triangle F O R E X_{t}=\alpha+\delta F O R E X_{t-1}+\varepsilon_{t}
$$

If $\beta=1 \leftrightarrow \delta=0 \leftrightarrow \triangle F O R E X_{t}=\alpha+\varepsilon_{t} \Rightarrow$ FOREX has a unit root or non-stationary. Vice verse, with $\beta<1 \Rightarrow$ FOREX do not have a unit root or FOREX is one stationary time series data.

The problem is how to estimate the value of $\delta$ ? The answer is $\delta$ is estimated by t-statistic. This problem is solved easier in the research of Dickey and Fuller with ADF test. According to this test, if absolute value of t-statistic of Augmented Dickey-Fuller test statistic larger than absolute value t-statistic of test critical value, then we have FOREX has a unit root, vice verse, FOREX is stationary variable.

We do the same method with variable stock prices of nine commercial joint stock banks in Vietnam, means variable FOREX in this model is changed to variable SP_ACB, SP_BID, SP_CTG, SP_EIB, SP_MBB, SP_NVB, SP_SHB, SP_STB, SP_VCB by roster.

With the non-stationary time series data, we can change it into stationary data by a change in level of it (Box, 1965).

\subsection{Var Granger Model}

Let foreign exchange rate $(F O R E X)$ and stock price of bank i $\left(S P_{i}\right)$ are stationary time series. To test the null hypothesis that FOREX does not Granger-cause $S P_{i}$, one first finds the proper lagged values of $S P_{i}$ to include 
in a univariate autoregression of $S P_{i}$ :

$$
S P_{i(t)}=\alpha+\beta_{1} S P_{i(t-1)}+\beta_{2} S P_{i(t-2)}+\cdots+\beta_{n} S P_{i(t-n)}+\varepsilon
$$

Next, the autoregression is augmented by including lagged values of FOREX:

$$
S P_{i(t)}=\alpha+\beta_{1} S P_{i(t-1)}+\beta_{2} S P_{i(t-2)}+\cdots+\beta_{n} S P_{i(t-n)}+\delta_{k} F O R E X_{t-k}+\cdots+\delta_{m} F O R E X_{t-m}+\varepsilon
$$

One retains in this regression all lagged values of FOREX that are individually significant according to their t-statistics, provided that collectively they add explanatory power to the regression according to an F-test. In the notation of the above augmented regression, $k$ is the shortest, and $m$ is the longest, lag length for which the lagged value of FOREX is significant.

The null hypothesis that FOREX does not Granger-cause $S P_{i}$ is not rejected if and only if no lagged values of FOREX are retained in the regression.

\section{Describe Data}

In order to run this model, we use data of foreign exchange rate VND/USD from January, $1^{\text {st }}, 2013$ to December, $31^{\text {th }}$, 2015. Until now, Vietnam has 5 stock markets, includes Hose stock market, HNX stock market, Upcom and OTC. Vietnam also has more than 50 commercial joint stock banks. However, there are only 9 commercial joint stock banks who have their stocks are quoted on two stock markets of Vietnam: 3 stocks of 3 commercial joint stock banks quotes on HNX stock market: ACB, NVB, SHB and 6 stocks of 6 commercial joint stock banks quotes on Hose stock market: BID, CTG, EIB, MBB, STB, VCB. The data about stock prices for this research is chosen from these banks in the same time period.

Table 1. List of commercial joint stock banks

\begin{tabular}{llll}
\hline & Stock code & Bank's name & Stock market \\
\hline 1 & ACB & Asia Commercial Bank & HNX \\
2 & BID & Joint Stock Commercial Bank for Investment and Development of Vietnam & Hose \\
3 & CTG & Viet Nam Joint Stock Commercial Bank for Industry and Trade & Hose \\
4 & EIB & Vietnam Export Import Commercial Joint Stock Bank & Hose \\
5 & MBB & Military Commercial Joint Stock Bank & Hose \\
6 & NVB & National Citizen Commercial Joint Stock Bank & HNX \\
7 & SHB & Sai Gon - Hanoi Commercial Joint Stock Bank & HNX \\
8 & STB & Sai Gon Thuong Tin Commercial Joint Stock Bank & Hose \\
9 & VCB & Joint Stock Commercial Bank for Foreign Trade of Viet Nam & Hose \\
\hline
\end{tabular}

Time is chosen for research is from December, $31^{\text {th }}, 2013$ to December, $31^{\text {th }}, 2015$ as to make the data as up-to-date as possible. Another reason for choosing this period is because the data is available for this time period for all variables under analysis. In particularly, with BID stock, time for research is chosen from January, $24^{\text {th }}, 2014$ to December, $31^{\text {th }}, 2015$. It is because of the date that BID started quoting on Hose stock market is January, $24^{\text {th }}, 2014$.

By graph, we can see that the VCB is the bank that its stock possesses highest price and fluctuates also strongest in this data. Unless NVB, other stocks of other banks also fluctuate strongly, specially in 2015, while the fluctuation of foreign exchange rate seems slowly. 


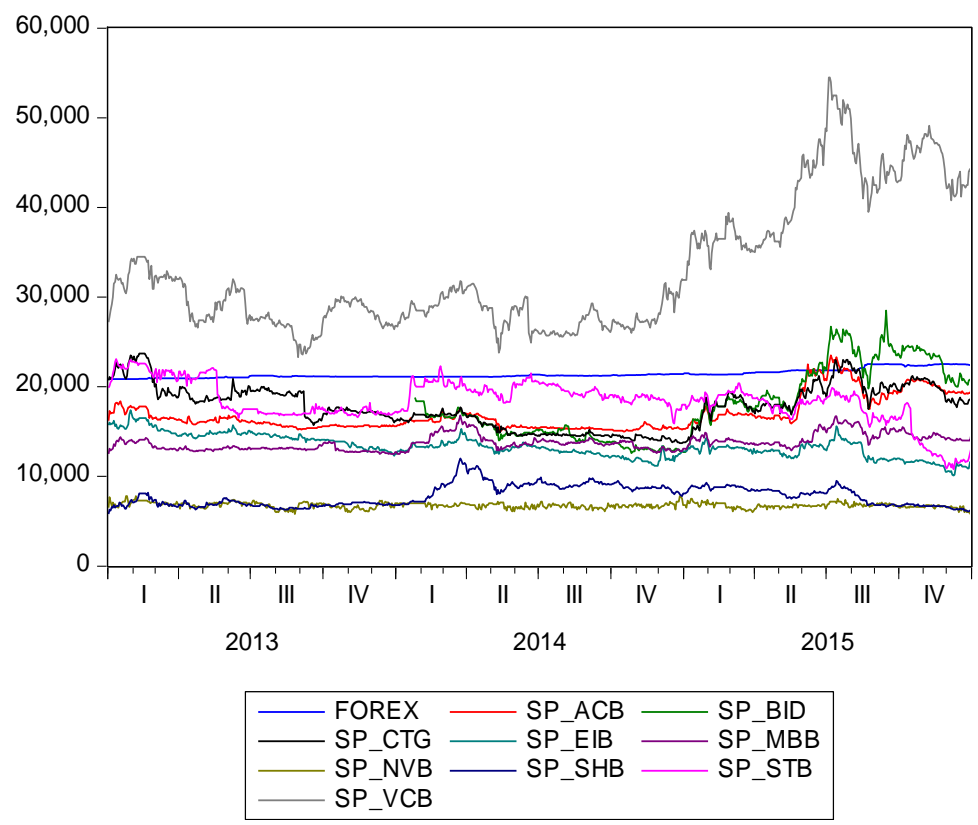

\section{Results and Findings}

In order to know the relationship between foreign exchange rate and stock price, we use Granger test, and one important requirement of this test is stationary data. Because of this reason, we have to check stationary of time series data by using Dickey-Fuller test first. The result of ADF test is showed through the table below:

Table 2. Result of ADF test

\begin{tabular}{|c|c|c|c|c|c|}
\hline \multicolumn{6}{|c|}{$\begin{array}{l}\mathrm{H}_{0}: \text { Variable is stationary. } \\
\mathrm{H}_{1}: \text { Variable is non-stationary. } \\
\text { If } / \mathrm{t}_{\text {stat (level) }} />/ \mathrm{t}_{\text {crit. }} 5 \% /=>\text { Accept } \mathrm{H}_{0} \\
\text { If } / \mathrm{t}_{\text {stat (level) }} /</ \mathrm{t}_{\text {crit. }} 5 \% /=>\text { Reject } \mathrm{H}_{0}=>\text { Change non-stationary data to stationary data by taking the } 1^{\text {st }} \text { difference (dif). If } / \mathrm{t}_{\text {stat(1st dif) }} \\
/>/ \mathrm{t}_{\text {crit. }} .5 \% /=>\text { Variable is stationary. If not, continue changing by using } 2 \mathrm{st} \text { difference. }\end{array}$} \\
\hline & Variable & $t_{\text {crit. }} 5 \%$ & $t_{\text {stat }}$ & $1^{\text {st }}$ dif & Conclusion \\
\hline 1 & FOREX & -2.87 & 0.54 & -26.72 & Stationary at lag 1 \\
\hline 2 & SP_ACB & -2.87 & -1.54 & -25.10 & Stationary at lag 1 \\
\hline 3 & SP_BID & -2.87 & -1.12 & -20.12 & Stationary at lag 1 \\
\hline 4 & SP_CTG & -2.87 & -2.06 & -26.61 & Stationary at lag 1 \\
\hline 5 & SP_EIB & -2.87 & -2.36 & -18.77 & Stationary at lag 1 \\
\hline 6 & SP_MBB & -2.87 & -3.10 & - & Stationary at level \\
\hline 7 & SP_NVB & -2.87 & -7.73 & - & Stationary at level \\
\hline 8 & SP_SHB & -2.87 & -2.05 & -28.47 & Stationary at lag 1 \\
\hline 9 & SP_STB & -2.87 & -1.55 & -27.80 & Stationary at lag 1 \\
\hline 10 & SP_VCB & -2.87 & -1.06 & -26.97 & Stationary at lag 1 \\
\hline
\end{tabular}

Hypotheses of stationary test of time series data is done by ADF test. For this test, we apply $5 \%$ significane for all variables. The results of its estimated show that there are 8 in 10 variables are stationary at lag 1 , it minuses 2 in 10 variables are not stationary in time period of research. In order to regularize time series data for research, we have to change 8 non-stationary (FOREX, SP_ACB, SP_BID, SP_CTG, SP_EIB, SP_SHB, SP_STB, SP_VCB) to stationary by taking the first difference of its (D(FOREX), D(SP_ACB), D(SP_BID), D(SP_CTG), D(SP_EIB), D(SP_SHB), D(SP_STB), D(SP_VCB)). The results after the first difference give us good data for running regression model, means all variables are stationary in research period.

After having stationary time series data, we can test relationship between foreign exchange rate and stock price of these commercial joint stock banks by using Granger test. And the results show as follow: 
Table 3a. Result of Granger test for impact of FOREX on SP

\begin{tabular}{|c|c|c|c|c|c|}
\hline & & & \multicolumn{2}{|c|}{ P-value } & \multirow{2}{*}{ Meaning } \\
\hline & & & Lag 1 & Lag 2 & \\
\hline \multirow{9}{*}{ Impact of } & \multirow{9}{*}{ FOREX on } & SP_ACB & $0.0619 * *$ & $0.0002 *$ & Impact at both lag 1 and 2 \\
\hline & & SP_BID & $0.0700 * *$ & $0.0009 *$ & Impact at both lag 1 and 2 \\
\hline & & SP_CTG & $0.5004 *$ & $0.0036^{*}$ & Impact at both lag 1 and 2 \\
\hline & & SP_EIB & $0.0135^{*}$ & $0.0209^{*}$ & Impact at both lag 1 and 2 \\
\hline & & SP_MBB & 0.1232 & $0.0020^{*}$ & Impact at both lag 1 and 2 \\
\hline & & SP_NVB & $0.0173^{*}$ & 0.1557 & Impact at lag 1 \\
\hline & & SP_SHB & $0.0971 * *$ & 0.2906 & Impact at lag 1 \\
\hline & & SP_STB & $0.0040^{*}$ & $0.0132 *$ & Impact at both lag 1 and 2 \\
\hline & & SP_VCB & $0.0714 * *$ & $0.0137 *$ & Impact at both lag 1 and 2 \\
\hline
\end{tabular}

*Has statistical meaning at 5\%; **Has statistical meaning at $10 \%$.

Table 3b. Result of Granger test for impact of SP on FOREX

\begin{tabular}{|c|c|c|c|c|c|}
\hline & & & \multicolumn{2}{|c|}{ P-value } & \multirow{2}{*}{ Meaning } \\
\hline & & & Lag 1 & Lag 2 & \\
\hline \multirow{9}{*}{ Impact of } & SP_ACB & & 0.2818 & 0.3838 & Does not impact \\
\hline & SP_BID & & 0.3101 & 0.2613 & Does not impact \\
\hline & SP_CTG & & 0.1710 & 0.3147 & Does not impact \\
\hline & SP_EIB & & 0.9308 & 0.8050 & Does not impact \\
\hline & SP_MBB & on FOREX & 0.5675 & 0.6474 & Does not impact \\
\hline & SP_NVB & & 0.9485 & 0.9591 & Does not impact \\
\hline & SP_SHB & & 0.7688 & 0.9524 & Does not impact \\
\hline & SP_STB & & 0.4730 & 0.4297 & Does not impact \\
\hline & SP_VCB & & $0.0996^{* *}$ & 0.2331 & Impact at lag 1 \\
\hline
\end{tabular}

*Has statistical meaning at $5 \%$; **Has statistical meaning at $10 \%$.

The results of Granger test show that the relationship between foreign exchange rate and stock price is one-way relationship, means only foreign exchange rate impact on stock price, and there is no opposite way of impact. In order to define exactly the relationship between stock price and foreign exchange rate, we use Vector Auto-regression Estimate (VAR method). The result is given as follow:

Table 4a. Result of vector auto-regression estimate for model relation between FOREX and SP_ACB

\begin{tabular}{lrc}
\hline Variable at lag & Coefficient & Vector \\
\hline FOREX(-1) & 1.040303 & Contra-variant \\
SP_ACB(-1) & -0.002561 & \\
FOREX(-2) & -0.041494 & Contra-variant \\
SP_ACB(-2) & 0.003297 & \\
\hline
\end{tabular}

Table 4b. Result of vector auto-regression estimate for model relation between FOREX and SP_BID

\begin{tabular}{lcc}
\hline Variable at lag & Coefficient & Vector \\
\hline FOREX(-1) & 1.038657 & Covariance \\
SP_BID(-1) & 0.003981 & \\
FOREX(-2) & -0.041318 & Covariance \\
SP_BID(-2) & -0.003517 & \\
\hline
\end{tabular}

Table 4c. Result of vector auto-regression Estimate for model relation between FOREX and SP_CTG

\begin{tabular}{lcc}
\hline Variable at lag & Coefficient & Vector \\
\hline FOREX(-1) & 1.043444 & Covariance \\
SP_CTG(-1) & 0.002392 & \\
FOREX(-2) & -0.043208 & Covariance \\
SP_CTG(-2) & -0.001924 & \\
\hline
\end{tabular}


Table 4d. Result of vector auto-regression Estimate for model relation between FOREX and SP_EIB

\begin{tabular}{lcc}
\hline Variable at lag & Coefficient & Vector \\
\hline FOREX(-1) & 1.042601 & Contra-variant \\
SP_EIB(-1) & -0.002688 & \\
FOREX(-2) & -0.041607 & Contra-variant \\
SP_EIB(-2) & 0.002774 & \\
\hline
\end{tabular}

Table 4e. Result of vector auto-regression Estimate for model relation between FOREX and SP_MBB

\begin{tabular}{lcc}
\hline Variable at lag & Coefficient & Vector \\
\hline FOREX(-1) & 1.041793 & Contra-variant \\
SP_MBB(-1) & -0.002600 & \\
FOREX(-2) & -0.041617 & Contra-variant \\
SP_MBB(-2) & 0.003352 & \\
\hline
\end{tabular}

Table 4f. Result of vector auto-regression estimate for model relation between FOREX and SP_NVB

\begin{tabular}{lcl}
\hline Variable at lag & Coefficient & Vector \\
\hline FOREX(-1) & 1.043189 & Covariance \\
SP_NVB(-1) & 0.000956 & \\
FOREX(-2) & -0.042359 & Covariance \\
SP_NVB(-2) & -0.001112 & \\
\hline
\end{tabular}

Table 4g. Result of Granger test for model relation between FOREX and SP_SHB

\begin{tabular}{lcl}
\hline Variable at lag & Coefficient & Vector \\
\hline FOREX(-1) & 1.043452 & Covariance \\
SP_SHB(-1) & 0.000749 & \\
FOREX(-2) & -0.042509 & Covariance \\
SP_SHB(-2) & -0.000532 & \\
\hline
\end{tabular}

Table 4h. Result of vector auto-regression estimate for model relation between FOREX and SP_STB

\begin{tabular}{lcc}
\hline \multicolumn{1}{c}{ Variable at lag } & Coefficient & Vector \\
\hline FOREX(-1) & 1.039982 & Contra-variant \\
SP_STB(-1) & -0.002365 & \\
FOREX(-2) & -0.037854 & Contra-variant \\
SP_STB(-2) & 0.002760 & \\
\hline
\end{tabular}

Table 4i. Result of vector auto-regression estimate for model relation between FOREX and SP_VCB

\begin{tabular}{lcc}
\hline Variable at lag & Coefficient & Vector \\
\hline FOREX(-1) & 1.041123 & Covariance \\
SP_VCB(-1) & 0.000749 & \\
FOREX(-2) & -0.044278 & Covariance \\
SP_VCB(-2) & -0.000428 & \\
\hline
\end{tabular}

When applying model for stock of Asia Commercial Bank, Vietnam Export Import Commercial Joint Stock Bank, Military Commercial Joint Stock Bank and Sai Gon Thuong Tin Commercial Joint Stock Bank, the results show that relationship between foreign exchange rate and stocks prices of these banks are contra-variant, while others are covariance. This means there is no exactly relationship between foreign exchange rate and stock prices of commercial joint stock banks in Vietnam.

\section{Conclusion}

This research examines the relationship between foreign exchange rate VND/USD and stock prices of nine commercial joint stock banks in Vietnam, the results show that the relationship between them is one-way relationship, that means there is an impact of foreign exchange rate on stock prices, while the change in stock 
prices do not cause the change in foreign exchange rate. However, the results also show that there is no exactly vector of impact, some are contra-variant, others are covariance. The results of this research can be seen as one evidence for impact of foreign exchange rate on stock price. In order to control stock price, the board managers of the commercial joint stock banks should examine factor foreign exchange rate. Stock investors should also analyze the change in foreign exchange rate when they give buying or selling decision.

\section{References}

Box, G. E. P. T., \& Georde C. (1965). A Change in Level of a Non-Stationary Time Series. Oxford University, 52(6). http://dx.doi.org/10.1093/biomet/52.1-2.181

Cheung, Y. W. L., \& Kon, S. (1995). Lag Order and Critical Values of the Augmented Dickey Fuller test. Journal of Business and Economic Statistics, 13(3). http://dx.doi.org/10.1080/07350015.1995.10524601

Desislava. (2005). The Relationship between Exchange Rate and Stock Prices: Studied in a Multivariate Model. Issues in Political Economy, 14.

Dickey, D. A. F., \&Wayne, A. (1979). Distribution of the Estimation for Autoregressive Time Series with a Unit Root. Journal of the American Statistical Association, 74(366). http://dx.doi.org/10.1080/01621459.1979.10482531

Dickey, D. A. F., \& Wayne A. (1981). Likelyhood Ratio Statistics for Autoregressive Time Series with a Unit Root. Journal of Econometrica, 49(4). http://dx.doi.org/10.2307/1912517

Izan, O. (1999). Stock and Currencies: Are they Related? Applied Financial Economics, 4, 637-660. http://dx.doi.org/10.1080/096031099332186

Kurihara, Y. (2006). The Relationship between Exchange Rate and Stock Prices during the Quantitative Easing Policy in Japan. International Journal of Business, 11(4).

Kutty, G. (2010). The Relationship between Exchange Rates and Stock Prices: The Case of Mexico. North American Journal of Finance and Banking Research, 4(4).

Lee, N. (2001). Dynamic Relationship between Stock Prices and Exchange Rate for G-7 countries. Quarterly Review of Economics and Finance, 47, 477-490. http://dx.doi.org/10.1016/S1062-9769(01)00085-0

Long, Đ. T. T. N., \& Phan T. (2010). Các phương pháp xác định rủi ro tỷ giá của ngân hàng thương mại. [Methodologies for measuring foreign exchange rate risk of commercial joint stock bank]. Journal of Banking, 8 .

Mahadeva, L. R., \& Paul. (2004). Unit Root Testing to Help Model Building: Bank of England. Handbooks in Central Banking.

Minh, L. T. H. H., Huynh, T. C., \& Hong, Đ. T. T. (2015). Độ nhạy cảm tỷ giá và tỷ suất sinh lợi chứng khoán. [Foreign exchange rate sensitivity and stock returns]. Journal of Science of An Giang University, 6.

Mougoue, A. (1996). On the Dynamic Relation between Stock Prices and Exchange Rates. The Journal of Financial Research, 19, 193-207. http://dx.doi.org/10.1111/j.1475-6803.1996.tb00593.x

Nga, L. T. H., Đao, T. T., \& Chien, N. M. (2013). Tác Động của Chính Sách Tỷ Giá tới Lạm Phát ở Việt Nam giai đoạn 2000-2012. [The impact of foreign exchange rate on inflation in Vietnam from 2000-2012]. Vietnam: Banking Science \& Training Review.

Sekmen, F. (2011). Exchange rate volatility and stock returns for the United State. African Journal of Business Management, 5, 9659-9664.

Tabak, B. M. (2006). The Dynamic Relationship between Stock Prices and Exchange Rates: Evidence for Brazil. International Journal of Theoretical and Applied Finance, 9(8). http://dx.doi.org/10.1142/S0219024906003974

Wickremasinghe, G. B. (2004). Efficiency of foreign exchange markets: A developing country perspective. SSRN Electronic Journal, 10(1). http://dx.doi.org/10.2139/ssrn.609285

Xiao, Z. P., \& Peter, C. B. (1998). An ADF coefficient test for a unit root in ARMA models of unknown order with empirical applications to the US economy. Econometrics Journal, 1. http://dx.doi.org/10.1111/1368-423X.12016

Yang, G. H. (2000). A Bivariate Causality between Stock Prices and Exchange Rates: Evidence from recent Asian flu. The Quarterly Review of Economics and Finance, 40(3), 337-354. http://dx.doi.org/10.1016/S1062-9769(00)00042-9 
Zhao, H. (2010). Dynamic Relationship between Exchange Rate and Stock Price: Evidence from China. Research in International Business and Finance, 24(2), $103-112$. http://dx.doi.org/10.1016/j.ribaf.2009.09.001

\section{Copyrights}

Copyright for this article is retained by the author(s), with first publication rights granted to the journal.

This is an open-access article distributed under the terms and conditions of the Creative Commons Attribution license (http://creativecommons.org/licenses/by/3.0/). 